Notes on a Journey Through the Western Himalaya

Author(s): T. G. Longstaff

Source: The Geographical Journal, Vol. 29, No. 2 (Feb., 1907), pp. 201-211

Published by: geographicalj

Stable URL: http://www.jstor.org/stable/1776536

Accessed: 27-06-2016 20:31 UTC

Your use of the JSTOR archive indicates your acceptance of the Terms \& Conditions of Use, available at

http://about.jstor.org/terms

JSTOR is a not-for-profit service that helps scholars, researchers, and students discover, use, and build upon a wide range of content in a trusted digital archive. We use information technology and tools to increase productivity and facilitate new forms of scholarship. For more information about JSTOR, please contact support@jstor.org.

The Royal Geographical Society (with the Institute of British Geographers), Wiley are collaborating with JSTOR to digitize, preserve and extend access to The Geographical Journal 


\section{NOTES ON A JOURNEY THROUGH THE WESTERN HIMALAYA.}

By T. G. LONGSTAFF, M.A., M.D.

THE following notes deal with portions of Kumaon, Nepal, Tibet, and Garhwal, which I visited in the course of a six months' journey last year (May to October, 1905), the distance covered being about 900 miles on the map. 'This journey was originally intended to be a purely mountaineering excursion, and I was accompanied by an Alpine guide from Courmayeur, Alexis Brocherel, with his brother Henri as porter.

I have already dealt with the mountaineering aspects of this trip in a previous number (August, 1906) of the Alpine Journal (vol. 23, pp. 202-226), to which I shall refer those interested in the subject. A considerable number of photographs of topographical interest were obtained. I estimated my altitudes with a $4 \frac{1}{2}$-inch Watkin aneroid by Hicks, which was constantly compared with the altitudes on the G.T.S. maps. In order to diminish the chances of over-estimating my heights, I gave the barometer only half a minute to settle after putting it into gear. In consequence, its readings were almost invariably higher than those shown on the maps, but I have made no allowance for this probable addition to my heights. I had no idea that I should be able to visit Tibet until I had left civilization behind, and was therefore unprovided with instruments and maps which I should otherwise have taken with me.

Leaving Almora on May 14, we proceeded by the usual but very interesting route to the head of the Milam valley, and pitched our camp close to the hamlets of Ganagarh and Panichu (altitude 11,100 feet) on May 27, our arrangements having been greatly facilitated by the kind help of Mr. C. A. Sherring, I.c.s., the deputy commissioner of Almora, and of Kishen Singh, Rai Bahadur, the Pandit 'A-K' of the transfrontier survey, whom we met at Mansiari. In the upper Milam valley, the strong wind (rani ka pankha of the foothills) which blows daily up the valley is very noticeable, and the general aspect of the country, with its climatic conditions, fauna, and flora, undergo a marked change, and, approximating to those of the neighbouring part of Tibet (Hundes), form an extraordinary contrast to the luxuriance of the semi-tropical region which has just been left behind.

The Bhotias had not yet come up to their summer quarters at Martoli and Milam in any considerable numbers, but we passed a few strings of grain-laden sheep, and ploughing with jhobus had just commenced. Though the main valley is practically treeless above Baugdiar (8550 feet), birch trees grow up to about 12,000 feet on the northwardfacing slopes of the lateral valleys, while rhododendron thickets extend 1000 feet higher. At Martoli I obtained specimens of the red-billed chough (Graculus eremita), which belongs rather to the Tibetan region,

No II.-February, 1907.] 
and is not nearly so common here as the Alpine chough (Pyrrhocorax alpinus).

Several days were Ispent on the Panchu glacier, which is at present, and has been for some time, receding. Flocks of Colomba leuconota and Accontor nepalensis were seen feeding about the snow-covered moraines up to 15,000 feet. The afternoons were generally cloudy, and there were some light rain and snow falls.

On June 2 we crossed a difficult snow-pass at the head of the Panchu glacier, directly under the south-eastern ridge of the eastern peak (24,379 feet) of Nanda Devi, its height being 17,750 feet, according to my Watkin aneroid. To our surprise we found ourselves at the head of the Lwanl valley, and not on the Kumaon-Garhwal waterparting as indicated on the G.T.S. maps. This pass, for which I would suggest the name Panchu, should only be crossed by experienced mountaineers, and no attempt should be made to take native coolies or shikaris over it. After a steep but easy descent, we found ourselves beside the rapidly shrinking glacier which rises below the eastern cliffs of Nanda-Devi (east peak), and descended the Lwanl valley, sleeping in the open some way below the summer grazing-ground of Narspan Patti, and regaining the main valley next day.

I was surprised by hearing the Bhotias use the word gal (pron. gull) for glacier, the identical word being in use by the Svans of the Western Caucasus.

On June 5 we started to ascend the Lwanl valley again to its head, making frequent use of great beds of winter avalanche snow, which completely covered the stream in many places, and gave an easy route up the glen for long distances. On June 8 we reached the KumaonGarhwal water-parting at 19,000 feet (Watkin), the last two days entailing climbing too difficult for the coolies (vide Alpine Journal, loc. cit.). From this point we looked (west) down upon the glaciers at the base of Nanda Devi, and (south) over the Pindri ridge and Traill's pass, which, tradition says, was regularly used long ago, to the Pindri glaciers, from which the Pindar river takes its origin. Next day we tried the south ridge of the east peak of Nanda Devi, but found it would take us at least two days more, for which we had insufficient food.

On June 10-11 we attempted to climb Nanda Kot from the summer grazing-ground of Narspan Patti (Schlagintweit, 13,404 feet; Watkin aneroid, 13,150 feet), but had to turn back at about 21,000 feet, owing to the danger of starting an avalanche.

On June 15 we started up the S'halung glen, which forms the south arm of the Lwanl valley, and on the 18th crossed a difficult pass (18,000 feet, Watkin), for which I suggest the name Ponting, in $18 \frac{1}{2}$ hours, being again without coolies. The Ponting glacier, on to which we descended, is crossed by three ranges of cliffs, the two lower of which completely 
interrupt it, except for a chaotic ice-fall. None of them are shown on the maps. The glacier is advancing, and its snout (11,600 feet, Watkin) presents a beautiful sight, the clear green ice being raised above the upper edge of the lateral and terminal moraines, and showing no tendency to lower its bed. At this spot I saw a mouse-hare (ochotona). This genus is widely distributed through the mountains of Kumaon, Nepal, Tibet, and Garhwal. I obtained specimens in the two latter regions, probably of different species, though the point has not yet been determined. For half a mile below the present termination of the glacier the ground is littered with huge boulders and grassy heaps of moraine stuff, amongst which are groves of rhododendron, birch, and pine, forming a delightful change to the treeless glens in which we had spent the last four weeks.

We reached our camp, which had been sent down to Bangdiar by the main valley, on June 19. Sherring having obtained leave for me to accompany him on his mission to Tibet, we proceeded back through the middle and tropical zones of the lower Gori to Askot, where we joined him on June 27.

Following the track along the right bank of the Kali river, which forms the frontier between Kumaon and Nepal, we reached Garbyang on July 8, having made the distance in eight marches. On July 3, at Tithla, I shot a pair of black-and-yellow grosbeaks out of a small flock in the forest of silver fir there, and am interested to find, on inquiring at the Natural History Museum, that the male was Pycnorhampus affinis, while the female was $P$. Icteroides, an interesting case of closely allied species frequenting the same ground, this being about the eastern and western limits of the two species respectively.

On July 9 I visited the Nampa glaciers (roughly indicated in Sheet 37 of the G.T.S., 1 inch = 1 mile), in search of Landor's Lumpa peak, 23,490 feet (vide Landor's 'Tibet and Nepal,' chaps. viii. and ix.). Sherring obtained for me two of the four Bhotia coolies who accompanied Landor on this trip, and I took seven others, in order that we might travel as fast as possible, our time being so limited.

Crossing the Kali just above Garbyang, we entered Nepalese territory, and soon came to the Tinker stream, which we crossed close to its junction with the Nampa stream. Crossing this also, we travelled along its left bank through beautiful woods of Pinus excelsa, and then over meadows of blue clover and red-blossomed strawberry to the glaciers. These are almost completely covered by surface moraine in the lower portion of their course, and are of great size, though the length of the main ice-stream does not now exceed 5 miles. Two large glaciers, about 4 miles long, separated by a high ridge, flow due north from Nampa peak into the main valley, but do not now join the main ice-stream. The lowest comes down to about 12,500 feet (Watkin), and presents the curious spectacle of having a split tongue. The first 
tongue, or snout, is stone covered; then comes a very old moraine area piled up about 100 feet, and dotted over with large silver birches. This is succeeded by the second snout at a considerable level above the first, and which I almost mistook for a separate glacier. I can only explain the formation by supposing that after the old terminal moraine was formed, the glacier began to advance again, and that the advancing snout of the glacier, far from removing the obstruction, was split into two tongues by the wedge-like opposition of the moraine, which was sufficient to keep the eastern arm at an elevation of at least 100 feet above that of the lower or western.

On July 10 we continued on up the main glacier to Landor's highest camping-place (13,200 feet, Landor ; 12,680 feet, Watkin). Leaving this camp sometime after 5 a.m., he states (op. cit.) that he ascended a peak of 23,490 feet, returning to the same camp at 6 p.m. Leaving most of our impedimenta here, we pushed on with Linka and Gobria, the two Bhotias previously mentioned, and reached the cairns he had erected in 1899. Having damaged my barometer at 15,300 feet, I am unable to do more than guess at the altitude, but believe it to be about 16,500 feet. I found no peak of 23,000 feet in the position indicated by Landor, and Nampa (23,352 feet) lies considerably to the south-west of his route. We returned as rapidly as possible by the same route, and reached Garbyang again on July 11.

Entering Tibet on July 14, in company with Sherring's party, by the easy Lipu Lekh (16,780 feet), we proceeded through Pala and Magram to Taklakot. According to Rawling ('The Great Plateau,' p 251), ours was the third European visit to this place; but, unlike our predecessors, we met with a most friendly reception. Taklakot (Purang) is the largest village in Hundes (Nari-khorsum), and at least equals, if it does not surpass, in importance the summer camp at Gyanema as a trade centre with British India. There are some poplars at Magramthe only trees I saw in Tibet. The altitude of Taklakot is given as 13,300 feet in the maps. The camping-ground is warm and sheltered. On July 16 the shade temperature was $76^{\circ}$ Fahr. at 2 p.m., and $54^{\circ}$ at 11 p.m. In the neighbouring rongs are several considerable hamlets, but Sherring has dealt with this district in his recently published 'Western Tibet and the British Borderland.'

I left Taklakot on July 18 with the two Brocherels and six Byanis Bhotias to examine the western flanks of Gurla Mandhata (Memo-NawNyimri of the G.T.S., Momo-nangli of Strachey, or Nimo-Numgyl of local Tibetans). The altitude of the culminating point is 25,350 feet according to the G.T.S. As long ago as 1864, Webber ('Forests of Upper India,' 1902) noted that the ascent of this peak would probably prove easier than that of any strictly Himalayan peak of an equal altitude, owing to the very high snow-line prevailing in this part of Tibet. 
Crossing the Karnali by a good wooden bridge above the big bend which this river makes to the east of Taklakot, we passed through the hamlet of De-la-ling, leaving the tomb of Zarawar Singh on the left. Soon afterwards we crossed the shallow stream of clear water which descends from the first and most southern gorge of the Gurla massif.

This gorge runs roughly from east to west, and is bounded on the north by the ridge which culminates in the G.T.S. peak, 22,200 feet. We met a large caravan of Tibetans, with many sheep and laden yaks, evidently bound for the wool market at Taklakot. Turning sharply to the east, we walked along the raised bank of the stream towards the foot of the ridge just mentioned. This raised bank bears a faint resemblance to an ancient moraine, and in the wide torrent bed are scattered large angular boulders, which looked from a distance as if they had been left there by a retreating glacier. We afterwardis looked down upon the whole extent of this steep-sided stony gorge. At its head is a relatively low col, with snow-streaked peaks springing up from it to the north and south, and other snow-streaked peaks rising into view beyond it to the east. No glacier was visible at the head of the gorge, and the $c o l$ appeared to form a true water-parting.

Commencing the ascent of the ridge itself at noon, we climbed steadily up steep but easy stone slopes for nearly six hours, and, sending the coolies down, camped for the night near the first beds of snow. The height of Bal-Dak is given in the G.T.S. as 15,000 feet, and we were higher than this at noon; considering, also, the complete absence of all vegetation, and size and character of the snow-beds on this south-west slope, I think that our altitude must have been over 18,000 feet.

The weather was cloudy on July 19, and I was suffering from headache, so we passed the day here. My barometer having been broken, and Sherring's hypsometer not being graduated low enough for use at these altitudes, I took the opportunity of tea-making to boil an air-thermometer. By plunging the bulb into the boiling water $I$ got the mercury to oscillate between $169^{\circ}$ and $170^{\circ} \mathrm{Fahr}$., which, of course, gives a hopeless result (almost 23,000 feet). The air temperature (11 a.m.) was $45^{\circ} \mathrm{Fahr}$, the sky being overcast and the sun quite concealed. The observation was comparable to the classical example at Pike's Peak observatory, when a pan of loose snow was set on a hot stove to melt, and in a short time the water in the bottom of the pan began to boil, while the snow on the top of it was yet 3 or 4 inches deep. Again, on July 22 the temperature of a kettle of boiling snow-water at about 20,000 feet was only $165^{\circ}$ Fahr., a result which was equally worthless for scientific as for culinary purposes.

This day (July 19) the Himalaya of Nepal and Kumaon were hidden by the clouds, but the view towards the west was very impressive. Kamet $(25,443$ feet) stood out boldly over the Niti pass at a distance of 100 miles. North of this was the Gangri range, partially snow-clad on its 
north-east slopes. Between lay a vast rolling plain, with rounded snowless hills rising from it, and a bend of the infant Satlej winding away into the north-west on its way to the Arabian sea, while the waters of the Karnali at our feet were flowing towards the Bay of Bengal.

On July 20 we got off at 2 a.m., in brilliant moonlight, the thermometer registering $29^{\circ} \mathrm{Fahr}$. The Himalaya of Nepal were visible long before sunrise, the first to catch the light being a very high and distant snow-peak bearing slightly east of south-east, and which we estimated to be over 25,000 feet in height. On reference to the map, it appears to be Dhaolagiri, distant 180 miles. Soon we saw Rakas Tal to the north, but Mansarowar remained hidden by the great western shoulder of Gurla. Passing over a steep dome-shaped snow-peak, we found ourselves on a narrow arête of snow, with our first uninterrupted view of the summit of Gurla. Below us was spread another glen, shut in by steep walls, and, like the first one already described, narrowing towards its outlet. The upper half (E) was filled by a large glacier, very white in colour, owing to the almost complete absence of moraine-stuff from its surface. For convenience I shall allude to it as the Gurla glacier. The ridge we were on led to the G.T.S. peak $(22,200$ feet), and then round in a northerly direction to the summit of Gurla. This route being obviously impracticable, we turned back as soon as a series of photographs (vide Alpine Journal, loc. cit.) had been secured.

I should like to put on record that the small map published in this Journal for 1900 to illustrate the journeys of the brothers Strachey in 1846-8-9, gives a more correct representation of the Gurla group than that retained in the latest sheets of the G.T.S. trans-frontier series. The huge southern glacier does not exist as shown in the latter. This locality lies well to the south of Major Ryder's recent survey; in fact, we were the first to see this side of the mountain, though the northern glaciers are plainly visible from the neighbourhood of Mansarowar lake.

Our next camp was made under an accommodating rock beside the stream flowing from the Gurla glacier, and close to an old lateral moraine, which extends into the open plain below the very constricted mouth of the gorge by which this stream leaves the mountains. Indeed, we found here a very good example of the relatively protective, rather than the destructive, action of a glacier, for the stream had cut deeply through a rocky barrier which had long resisted the action of moving ice.

We next (July 22-23) ascended the great western ridge of Gurla to a height of about 23,000 feet, looking down on to and over the G.T.S. peak, 22,200 feet. This route proving too long and exposed (vide Alpine Journal, loc. cit.), we tried to follow up the Gurla glacier and the south-west face of the mountain, but after spending two nights in the open at very high altitudes, the continual exposure and want of food compelled me to give up the attempt. 
During our descent of the Gurla glacier on July 25, we found that the dry glacier was too rough to follow, apparently owing to surface evaporation caused by the extreme dryness of the atmosphere. For the same cause the glacier stream itself is a very small one. A similar condition has been noted by Freshfield and Mumm on Ruwenzori. The snout of the glacier shows signs of actual recession at the present time. There were several beds of dead ice protected by moraine-stuff below the snout, and these were succeeded by typical glacial pools. Unfortunately, all the plants I collected during this excursion were lost. Of the animals, burrhel (Ovis nahura) ranged up to and above the snow-line. One mouse-hare (Ochotona, ? sp.) was seen about 17,000 feet. Woolly hares (Lepus oiostolus) were common on the lower slopes of the peak, where there were also a few small colonies of marmots (? sp.). On the plain, about Bal-dak (15,000 feet) were a few kiang and goa (Gazella picticaudata). I also saw two black wolves (Tib. Hakpo-chanko).

Rejoining Sherring on July 29 at the south-west corner of Mansarowar (Mo-bang), we marched the next day along the neck of land which separates this lake from that of Rakas (La-gang), and camped on the shingle beach below Jiu Gom-pa, having crossed the partially dry, but deeply cut, connecting channel at the hot springs. The east end of the channel was closed by a raised bank of shingle, apparently due to wave-action, although there are signs, especially on the low cliffs at the north-west corner, that the level of the lake has fallen in recent times. Sherring obtained an excellent panoramic photograph showing portions of both lakes and the whole length of the connecting channel ; an enlargement of this is now hanging in the Society's Map Room.

I accompanied him on his road to Gartok, past the beautiful peak of Kailas, and as far as Missar, following the route recently described by Rawling, and traversed in part by Moorcroft and Hyder Hearsey in 1812. Woolly hares, mouse-hares, ground-choughs (Podoces humilis), a small flattish sandy-coloured lizard, and a locust (Bryodema inda vel $s p$. n.), whose appearance when flying curiously resembles that of Vanessa antiopa, were the commonest forms of animal life, while kyang and goa were occasionally seen. I also obtained here a pair of sandplovers (Ochthodromus pyrrhothorax, Sharpe), with nestling. The plains were covered with a low growth of dama (Caragana pygmoa), which with yak droppings formed the only fuel we ever obtained in Tibet.

From Missar I turned off to Tirthapurri, on the Satlej, the ground between the two places being often completely covered with a plant indistinguishable from the edelweiss of the Alps. There are some hot springs of great repute at the latter place, which have formed welldefined encrusted terraces near the river. An indescribably filthy monastery, some shrines, and mendongs were shown me, said to be the goal of many pilgrims, both Buddhist and Hindu. 
On August 7 we forded the Satlej half a mile above Tirthapurri, and, making two long and difficult marches through the almost waterless hills of Chitumb, reached Gyanema late at night on August 8. The fair was in full swing, and a great trade in wool was going on. Owing to illness, probably caused by bad water, I was confined to my tent for a week, and afterwards had to give up walking and ride a yak, so that my opportunities of examining the neighbourhood were very limited. The lake is smaller than at the time of the Stracheys' visits, and its western end is surrounded by soft mud flats, on which were a few ducks and waders. I visited what I supposed were the ruins of the "fort," on a small hill between the Tibetan and Bhotia camps, but found only some ruinous chortens and mendongs. The Tibetans were quite friendly, and supplied me with yaks to continue the journey.

Leaving Gyanema on August 18, we reached Shibchilam on August 20 , the three days' march being across an almost level shingly plain covered with clumps of dama about a foot high. Strachey's comparison of this plain to a vast lake is singularly apt, the mirage assisting in the delusion. On the way we forded the Darma Yankti, Gan Yankti, and $\mathrm{Chu}-\mathrm{Naku}$, all rapid glacier streams with only slightly sunken beds. The former is undoubtedly, as Sir Henry Strachey suggested in 1846, the longest branch of the headwaters of the Satlej, while the three streams which combine to form the Chu-Kar must carry a greater volume of water than the Satlej where I forded it at Tirthapurri. Gurla was the most prominent object in view, but the Himalaya to the south were constantly visible. The weather was very clear and often oppressively hot, and the daily southerly wind and dust devils were trying. Each evening as the sun set, diverging rays of bright pink light shot up into the eastern sky: gradually the dark shadow of the earthclearly visible at first, but soon becoming indistinct-crept up and blotted out this beautiful sight.

Shibchilam lies in a deep gorge on the left bank of the Tok-pu. The sections consist entirely of coarse gravel, with rounded and subangular stones embedded in it. Both Tibetans and Niti Bhotias were in camp here. The Dzong-pon of Daba paid me a visit and arranged for a relay of yaks.

On August 22 we made our last march across the plain, which is, however, deeply scored by numerous steep-sided gravelly ravines, all trending towards the Satlej. The present rainfall is obviously insufficient to have cut them out, and we have here another piece of evidence of the increasing dryness of the climate, though we had the unusual experience of a sleet-storm at starting, and flowers and grass were becoming more common amongst the everlasting dama as we reached the Dakkar ihills. We had much trouble with the new yaks, which were constantly casting their loads and breaking away, and the day's march of about 9 miles occunied seven hours. 
August 23 was spent at Dakkar to collect yaks from another herd. Now that we were actually in the hills the wind was worse than ever. Nevertheless, sulphur-yellow butterflies and the common Tibetan locust (Bryodema inda, vel sp. n.), with an unnamed wingless species (? near Ataxius), were common. I also shot one of a pair of warblers ( $\boldsymbol{P}$. affinis), and tried in vain to get near a dark-coloured tern that was hawking over the small stream.

Dakkar is surrounded by hills with strangely contorted pinnacles of red rock protruding from their sides. On August 24, accompanied now by only two Tibetans and two Garhwalis, we made a short march south-west into the "Red Hills," getting a view of Kamet on the way, and camped in a wild windy glen. This is a noted region for Ovis ammon (Hodgsoni), but except for two skulls we saw no signs of them. On August 25 we made our last march in Tibet. Leaving our lonely camp, we continued along a narrow ravine in a south-south-west direction, and crossed a high grassy ridge at an altitude of about 17,000 feet. Below us, to the west, was spread another great plain, similar to that we had already traversed, and across which lies the route from the Niti pass to Daba. A very steep descent led down to a broad but shallow stream, here flowing west. This spot is called Sag, and here we saw the last Kyang, and also a pair of terns, which seemed strangely out of place. We turned nearly due south up a side stream, the valley getting rapidly narrower, with steep bare stony sides. On the way several beds of permanent ice (dar) were crossed, through one of which the yaks passed by a natural tunnel. I attribute them to avalanches of winter snow, which remain unmelted year after year, partly owing to the protection afforded by the stones and shale which cover their surface, and partly to the narrow and sunless character of the gorges in which they lie. The sky, too, is generally more cloudy and overcast here as the Himalayan chain is approached, and neither is the heat of the sun nor the dryness of the air so extreme as it is further north and east. Sir Richard Strachey has noted similar accumulations in Pangong and Rupshu (Journal R.G.S., vol. 23, p. 54). After a very long march, we crossed the Shelshel pass (16,300 feet) into Garhwal and camped at Hoti, having completed a journey of about 300 miles in this interesting, if much-visited, corner of Tibet, where for six weeks we had seldom been at a lower altitude than 15,000 feet. In taking leave of Tibet, I cannot refrain from recording my appreciation of the various accounts of this region which we have received from the Stracheys. Their narratives of sixty years ago constitute a record of the country and the people which is still unsurpassed.

This small corner of Garhwal, although to the south of the true Himalayan water-parting, is still Tibetan in character, though the grass is much more luxuriant. The Shelshel pass is relatively low, and the snowy range lies still to the south and west. But the whole of the 
Hoti, Laptal, and Topi-dunga valleys are cut off by the narrow and extremely difficult defile of the Girthi river, and remain uninhabited. I saw no trees until we had crossed the Chorhoti pass (18,500 feet) on August 28. Marmots, of which we shot and ate several specimens, are very numerous here. I never saw them in any other locality of Kumaon or Garhwal, though they are reported to be found as far south as Trisul.

We now followed the course of the Dhaoli river, amongst what is perhaps the wildest scenery to be met with in the Himalaya, to Tapoban. Whether one tries to enter the higher ranges by the valley of the Kali, the Gori, or the Dhaoli, geographically the three chief rivers of these mountains, a zone of profound narrow and precipitous defiles is encountered, which separates the middle ranges from the more open and gently graded upper valleys into which the glaciers discharge. But of the three, the most savage and picturesque are those defiles of the Dhaoli on either side of Malari. At Tapoban we struck up over the middle ranges to Gwaldam.

Leaving Gwaldam on September 26, we reached the foot of the Kurumtoli glacier on October 1, after five hard marches, the distance as the crow flies being less than 19 miles. Our camping-place was called Mulkhet by the Garhwalis; they apply the name Kurumtoli to a grazing-ground and glacier on the western slopes of Trisul. Nevertheless, the nomenclature of the G.T.S. must be respected.

We explored this glacier on October 2-3, believing that it would lead us to the highest peak of Trisul (23,406 feet). We found, however, that a continuous line of cliffs runs due west from A 28 (22,490 feet) to the middle peak of Trisul, and that the water-parting between the Rishi Gunga and the Pindar river is displaced about 2 miles to the north on the G.T.S. maps. The glacier which is shown flowing into the Kurumtoli from the east does not enter this valley at all, but whether it flows north into the valley of the Rishi Ganga, or south-east into the Sukeram glacier, I could not see. I trust it will be realized that I speak of the work of the Indian Survey in no critical mood. With the funds at their disposal, it has been quite impossible to survey the glacier regions with any approach to detail, and it is surprising that so great a degree of accuracy has been obtained in regions so difficult of access, and which are of no importance for political or revenue purposes.

From my kind host at Gwaldam, Mr. Robert Nash, who has been many years in Garhwal, I learnt of an old pass directly to the west of Trisul, which was many years ago frequently used. Colonel E. Smyth, who selected the late Nain Singh, c.I.E., and Kishen Singb, Rai Bahadur, for the trans-frontier survey, speaks of a pass from Ralam in Johar, into the Darma valley, which he crossed with great difficulty, and which was, according to Bhotia tradition, long ago easy of passage. I have mentioned the similar case of Traill's pass over the Pindıi ridge. Such 
cases may be due merely to local changes in these particular glaciers, but one cannot help remembering the evidence brought forward by Blanford, Garwood, and others to the effect that the Himalaya are still undergoing a process of elevation. Such elevation, by arresting an increasing amount of the monsoon water-vapour, would surely be at least a contributory cause in the desiccation now taking place in Central Asia, indications of which are evident even in regions so close to the Himalaya as Mansarowar.

In concluding these notes, I must express my gratitude to my two Italian companions, who served me well and uncomplainingly during a long journey, which was not without a good deal of hardship and sometimes danger, and of whose technical abilities I cannot speak too highly.

\section{NOTES ON THE WORK OF THE FRENCH GEODETIC EXPE- DITION TO MEASURE THE QUITO ARC.}

In 1898 the International Geodetic Conference passed a resolution that steps should be taken to remeasure the arc of meridian at the equator, which was first measured in the eighteenth century by Bouguer, La Condamine, etc. The French representatives at this conference accepted the responsibility of undertaking this, and the duty was assigned to the geodetic section of the Service Geographique de l'Armée, of which General Bassot, member of the Institut, was director, Commandant Bourgeois of the Artillery being head of the geodetic section. The first detachment of geodesists, Captain Maurain of the Engineers and Captain Lacombe of the Artillery, landed at Guayaquil in 1899. They were instructed to make a general reconnaissance of the mountain chain, and prepare the way for the rest of the expedition.

In 1900 Commandant Bourgeois, accompanied by Captain Lallemand and Lieut. Perrier, both of the Artillery, with the physician attached to the expedition, Dr. Rivet, médecin aide major, arrived at Guayquil. They at once proceeded to measure a base at Riobamba, and to determine the difference in longitude between Quito and Riobamba.

The arc measured in the eighteenth century was only $3^{\circ}$ long. It was decided to double this length by prolonging the measurements northwards as far as the Colombian frontier, and southwards into Peru as far as the environs of Piura. The work in Equador was carried on during $1900,1901,1902,1903$, and 1904, first under the direction of Captain Maurain (Commandant Bourgeois having returned to France after a stay of about six months in the field), and then of Captain Massenet, who died at Cuenca in September, 1905.

In 1902 Captain Maurain went to Payta to study the terminal part of the chain of triangulation, built an observatory, and then determined its astronomical latitude. In 1905 Captains Peyronnel and Lallemand, 